\title{
Misoginisme dalam Novel Kim Ji-yeong, Lahir Tahun 1982 Karya Cho Nam-joo: Kajian Feminisme Sastra
}

RINA HUSNAINI FEBRIYANTI rhfebriyanti@gmail.com Program Studi Pendidikan Bahasa Inggris, Universitas Indraprasta PGRI

ZURIYATI

zuriyati@unj.ac.id

SAIFUR ROHMAN

saifurrohman@unj.ac.id

Program Studi S3 IImu Pendidikan Bahasa, Universitas Negeri Jakarta

Jakarta, Indonesia

dikirim: 23/6/2020 diperbaiki: 8/10/2020 diterima: 17/10/2020 DOl: 10.22515/ljbs.v5i2.2571 hlm: 159-176

ABSTRACT A woman deserves to get respect and equal position with a man in the feminist view. This study aimed to find out misogynism in the novel Kim Ji-yeong, Lahir Tahun 1982, written by Cho Nam-joo. The method was qualitative. The collected data was from words, phrases, clauses, and sentences, whether directly or indirectly stated by women characters in the novel affected by misogyny. Data analysis based on Bogdan \& Biklen model (2007) was categorized and coded; afterward, it was interpreted and displayed descriptively. The result revealed three situations described they were misogyny in the domestic area, society, and institution. This study implies in the feminist perspective that it is crucial to avoid or prevent misogynism in lives.

Keywords: misogynism, novel, feminism

PENDAHULUAN Sastra didefinisikan sebagai komposisi yang menggambarkan sebuah imajinasi yang dapat berupa cerita lisan ataupun tulisan (Fowler 2006). Dalam lisan dan tulisan terdapat susunan di mana terbentuk dari imajinasi yang diolah sedemikian rupa ke dalam sebuah karya yang dapat dinikmati oleh para pendengar, pembaca, atau penonton. Imajinasi yang dituangkan dalam sebuah sastra yang pada umumnya dipahami sebagai hal yang tidak nyata atau yang diciptakan (Eagleton 2005). Sastra menyampaikan pengetahuan suci, mengajarkan pelajaran moral dan sosial, mengumumkan ide-ide baru, mencatat revolusi, menguji batas-batas nilai-nilai budaya, dan menunjukkan kepada kita yang terbaik dan terburuk dari diri kita (Kusch 2016). Selain itu, terdapat pemahaman mengenai ilmu sastra yakni ilmu yang menyelidiki karya sastra, beserta gejala yang menyertainya, secara ilmiah. Di samping teks karya sastra, juga semua peristiwa dan fakta- fakta sosial yang berkaitan dengan keberadaan karya sastra, pengarang, pembaca, lembaga penerbitan, media massa, dan sebagainya, yang menjadi objek penyelidikan (Suhariyadi 2014). Pemahaman mengenai sastra semakin berkembang sejak abad ke-19, pengertian sastra yang lebih luas sebagai totalitas karya tulis atau cetak telah memberi jalan kepada definisi yang lebih eksklusif berdasarkan kriteria nilai imajinatif, kreatif, atau artistik, yang terkait dengan tidak adanya referensi faktual atau praktis (Baldick 2001).

Karya sastra merupakan karya yang dihasilkan tidak lepas dari tradisi atau konteks budaya(Croally \& Hyde 2011). Hal ini dapat digambarkan bahwa karya sastra yang diciptakan dapat diperoleh dari inspirasi tradisi dan budaya penulis yang direfleksikan dalam karya yang ditulis. Pascale Casanova dalam William (2019) berpendapat bahwa apa yang tampaknya paling asing bagi sebuah karya sastra adalah, konstruksinya, bentuknya, dan singularitas 
estetisnya, pada kenyataannya adalah apa yang menghasilkan teks itu sendiri, yang memungkinkan karakter individualnya menonjol. Karya sastra dapat berupa fiksi atau nonfiksi yang terpisahkan dari cerita yang ditorehkan apakah diambil dari cerita fakta (nonfiksi) atau karangan (fiksi). Karya sastra fiksi adalah suguhan linguistik yang memproyeksikan dunia fiksi yang mencakup pembicara, aktor, acara, dan audiens tersirat serta mengacu pada imajinasi dari pengalaman historis seseorang, namun fiksi tidak hanya terbatas pada tokoh dan peristiwa saja melainkan juga pada aspek secara keseluruhan dalam karya tersebut (Culler 2000). Istilah sastra meliputi karyakarya seperti genre utama yakni epik, drama, lirik, novel, atau cerpen(Cuddon 1999).

Salah satu dari tipologi karya sastra adalah novel atau secara klasik dikenal dengan istilah prosa. Novel berasal dari bahasa Italia yaitu novella yakni kisah sepotong cerita yang diterapkan pada berbagai tulisan yang lebih luas, di mana atribusi kisahnya lebih panjang sebagaimana dalam prosa fiksi (Abrams 1999; Baldick 2001; Cuddon 1999; Drabble 2000). Topik prosa fiksi diantaranya seperti dongeng moral, sindiran sosial, biografi imitasi dan autobiografi, investigasi sentimental, narasi aksi, eksplorasi erotis, dan berbagai kombinasi lainnya (Arata et al. 2015). Seperti yang disampaikan oleh Holland (2019) novel merupakan media yang terus-menerus beradaptasi dan memiliki kemampuan untuk menyerap bahan dari berbagai sumber, menggabungkan dan memodifikasi bahan tersebut sesuai dengan tujuannya. Selain itu semakin berkembangnya novel terdapat pula ide cerita yang muncul seperti melambangkan kekuatan-kekuatan modernitas yang baru, budaya konsumerisme, ilmu pengetahuan baru, jurnalisme, sekularisme, domestikitas, lingkup publik, dan subjek liberal (Parker \& Smith 2014). Lain halnya dengan novel sejarah di mana menempatkan novel bukan hanya sebagai fenomena lokal, regional, tetapi telah menjadi, selama era postmodern, alat transnasional untuk mengeksplorasi bagaimana harus berpikir tentang bangsa dan nasionalisme dan seperti apa masyarakat seharusnya atau tidak seharusnya terlihat (Brantly 2017). Dengan bergulirnya kemajuan pada novel tema cerita yang diangkat di dalamnya semakin bervariasi mulai secara historis bertemakan religi, moral, natural, misteri, romansa,kolonial, pasca kolonial, sejarah, biografi dan masih banyak lagi sampai kepada tema yang berkisah tentang feminim.

Lahirnya tema feminin pada novel mencitrakan eksistensi perempuan dalam sebuah karya sastra yang sebelumnya didominasi oleh pria di mana posisi perempuan berada pada posisi yang tidak istimewa atau hanya biasa saja (Mackay 2010). Kemudian muncullah persepsi atau gerakan yang disebut dengan feminisme. Feminisme berasal dari bahasa latin yaitu kata femina yang diartikan dengan keperempuanan (Emzir \& Rohman 2017). Feminisme sendiri muncul didasari oleh budaya macho (mengutamakan kepentingan laki-laki) di mana perempuan hanya bergelut pada urusan domestik rumah tangga saja sementara untuk laki-laki dapat bebas menjelajah atau melakukan apapun (Cruz \& Languages 2012). Selain itu, pemikir tentang feminisme beranggapan bahwa eksistensi mereka di dunia secara sosial membutuhkan kebebasan seperti halnya laki-laki (Welch 2012). Terdapat beragam jenis feminisme diantaranya: (1) feminisme liberal yakni pandangan untuk menempatkan perempuan yang memiliki kebebasan secara penuh dan individual; (2) feminisme radikal yakni perjuangan separatisme perempuan; (3) feminisme postmodern yang berpandangan anti absolut dan anti otoritas; 
(4) feminisme marxis yakni memandang masalah perempuan dalam kerangka kritik kapitalisme; (5) feminisme postcolonial yaitu pandangan yang berakar dari pengalaman hidup dunia ketiga (koloni/bekas koloni); (6) feminisme anarkis dimana berpandangan laki-laki sebagai sumber kehancuran; dan (7) feminisme sosialis berpandangan bagaimana peranan perempuan dalam kondisi sosial (Suhariyadi 2014). Pengertian secara mendasar mengenai feminisme dibedakan menjadi dua; pertama adalah perbedaan gender di mana ketidaksetaraan pondasi struktural antara laki-laki dan perempuan yang ditunjukkan dengan sistem ketidakadilan sosial pada pihak perempuan yang menderita karenanya, dan kedua yaitu bahwa ketidaksetaraan antar jenis kelamin bukan hasil dari kebutuhan biologis tetapi dihasilkan oleh konstruksi budaya dari perbedaan gender (Morris 1993). Perbedaan dari persepsi fisik dan sosial inilah yang kemudian menjadi acuan dalam diciptakannya novel yang bertemakan feminisme. Kehadiran feminisme merupakan gejolak yang menyuarakan tentang pentingnya feminisme bagi kehidupan perempuan, kesetaraan, rasa hormat, dan keadilan sosial bagi perempuan meskipun demikian masih dirasakan jauh untuk mencapai hal-hal tersebut (Logan 2011).

Salah satu topik pembahasan dalam feminisme adalah misoginisme. Etimologis kata misogini (misogyny) berasal dari bahasa Yunani yakni misogynia; miso (benci); gyne (wanita) yang bermakna a hatred of women, yang berkembang menjadi Misoginisme (mysogynism), secara hakikat adalah suatu ideologi yang membenci wanita (Sunarto 2009). Misoginis menyiratkan aspek yang secara terang-terangan dan keras seperti kekerasan pasangan intim (juga disebut kekerasan dalam rumah tangga), penganiayaan seksual, pelecehan di jalan, dan menilai seorang wanita hanya berdasarkan penampilannya (Ukockis 2019). Sistem misoginis menganggap wanita tidak sempurna sedangkan pria itu sempurna, pria adalah segalanya dan wanita bukan apa-apa, wanita sebagai orang yang memalukan, lemah, dan membutuhkan keamanan pria. Mereka menyarankan bahwa kejantanan tidak lengkap kecuali dia menyinggung, menghina, dan mengendalikan seorang wanita. Laki-laki bukan laki-laki kecuali dia mampu memiliki kekuasaan atas otonomi perempuan (Sharawi 2017). Bahkan perlakuan misoginis dilakukan secara terang-terangan dan keras seperti kehidupan publik, termasuk perempuan dari semua jenis perempuan misalnya, demonstran, juru bicara, pekerja, pasien medis, ibu, dan pemimpin perempuan sehari-hari lainnya, dan masih banyak lagi (Wachtell \& Wolf 2017). Selain itu, ketidaksetaraan dalam ras kelas sosial, orientasi seksual, dan letak geografi termasuk dalam perlakuan misoginis (Anderson 2015). Dalam misoginisme terdapat juga apa yang disebut dengan infantilisasi dan meremehkan, mengolok-olok, mempermalukan, mengejek, mencaci maki, menjelekkan, juga melakukan pelecehan seksual atau, sebagai alternatif, tidak memberadakan jenis gender perempuan, membungkam, menghindar, mempermalukan, menyalahkan, mempatronisasi, merendahkan, menyepelekan, dan bentuk-bentuk tindakan lain yang bersifat meremehkan dan merendahkan dalam konteks sosial tertentu, kemudian terdapat juga kekerasan dan perilaku mengancam dengan kekerasan fisik seperti meninju, memukul, menendang dan sejenisnya (Manne 2018). Seiring dengan perkembangan zaman dan teknologi misoginisme juga masuk dalam ranah teknologi seperti melalui video, jejaring sosial, media layar kaca, telefon pintar (telefon seluler) dan media interaktif (Anderson 2015; David 2016; Mantilla 2015; Tracy \& Everbach 2018; Zuckerberg 2018). 
Novel Kim Ji-yeong, Lahir Tahun 1982 karya Cho Nam-Joo merupakan novel yang dicetak di Korea Selatan pada tahun 2016 yang kemudian dicetak di Indonesia kali pertama pada tahun 2019. Novel tersebut berkisah tentang seorang wanita yang bernama Kim Ji-yeong yakni anak perempuan yang terlahir dalam keluarga yang mengharapkan anak laki-laki, dan menjadi bulan-bulanan para guru pria di sekolah, dan yang disalahkan ayahnya ketika ia diganggu (anak laki-laki dalam perjalanan pulang dari sekolah di malam hari). Kim Ji-yeong merupakan mahasiswi yang tidak pernah direkomendasikan dosen untuk pekerjaan magang di perusahaan ternama, karyawan teladan yang tidak pernah mendapat promosi, dan istri yang melepaskan karir serta kebebasannya demi mengasuh anak. Kim Ji-yeong mulai bertingkah aneh yaitu mulai mengalami depresi. Kim Ji-yeong adalah sosok manusia yang memiliki jati dirinya sendiri. Namun, Kim Ji-yeong adalah bagian dari semua perempuan di dunia. Kim Ji-yeong, Lahir Tahun 1982 adalah novel sensasional dari Korea Selatan yang ramai dibicarakan di seluruh dunia. Kisah kehidupan seorang wanita muda yang terlahir di akhir abad ke-20 ini membangkitkan pertanyaan-pertanyaan tentang praktik misoginis dan penindasan institusional yang relevan saat ini. Cho Nam-joo lahir tahun 1978 di Seoul. Setelah lulus dari Fakultas Sosiologi, Universitas Ewha, ia bekerja selama sepuluh tahun sebagai penulis program TV terkait isu-isu terkini, seperti PD Note, Consumer Reports (Complaint Zero), Live This Morning (Cho 2020).

Beberapa studi atau kajian yang meneliti mengenai aspek misoginisme seperti Magennis (2016) menganalisis mengenai seorang tokoh yang bernama Spector di mana melakukan tindakan misoginis seperti kekerasan terhadap pasangan, pemerkosaan, pelecehan anak perempuan, dan meneror anak perempuan yang dikisahkan berada di negara Irlandia utara dalam serial drama The Fall. Selanjutnya Benedetti (2016) yang mengkaji tokoh perempuan dalam novel Digongan yang diceritakan di zaman akhir Dinasiti Qing, yang mana sikap penulis secara substansial bergantung pada retorika seksis yang lazim dalam gagasan konfusianisme tentang masyarakat tertata, yang biasanya mengambil pandangan negatif terhadap perempuan yang mengambil bagian dalam kehidupan publik dan tindakan-tindakan misoginis yang dikaitkan dengan wacana politis. Hasil studi lainnya dilakukan oleh Nguyen dkk. (2018) mengkaji mengenai puisi dari John Donne yaitu Elegy 19 yang dalam puisi tersebut mengandung kata-kata berimplikasi secara misoginis seperti To His Mistress Going to Bed di mana perempuan hanya ditempatkan sebagai objek laki-laki dan peran laki-laki dengan tindakannya yang misoginis di mana cenderung menguasai dan mendominasi terhadap perempuan yang digambarkan dengan posisi secara tidak setara dengan lakilaki. Lain halnya dengan Fischer (2016) menganalisis tokoh Lolita sebagai protagonis dan ayah tirinya Humbert sebagai antagonis yang terus melakukan provokasi, pelecehan seksual dan kekerasan fisik terhadap Lolita meskipun ia adalah anak tirinya sendiri dengan menginfuskan konsep cerita The Little Mermaid sebagai landasan bahwa pengorbanan seorang perempuan untuk laki-laki adalah hal yang wajar sehingga memicunya untuk menuruti segala kemauan laki-laki. Berbeda dengan Bala \& Blessy (2020) mengkaji tentang ignominis dan misoginis dimana dalam novel The Inheritence of Loss yang ditulis oleh Kiran Desai dengan konteks kultur negara India yang di dalam novel tersebut mengungkapkan perempuan adalah makhluk yang lemah dan semata-mata dijadikan objek laki-laki dan 
tokoh perempuan diperlakukan dengan buruk, direndahkan, bahkan dipermalukan dengan kekerasan di depan umum untuk menunjukkan dominasi laki-laki.

Kajian mengenai misoginisme dalam karya sastra masih belum banyak dilakukan, oleh karena itu dalam studi ini akan mencoba menguakkan tindakan seperti apa sajakah yang tergolong dalam misoginis melalui novel Kim Ji-yeong, Lahir Tahun 1982 karya Cho Nam-joo serta kaitannya dengan feminisme.

METODE Metode penelitian yang digunakan dalam studi ini adalah kualitatif yang PENELITIAN salah satu cirinya berupa deskripsi yang diperoleh dari hasil teks yang ditafsirkan berdasarkan klasifikasi tema yang dijadikan sebagai temuan (Creswell 2012). Penelitian kualitatif juga mengacu pada pengumpulan, analisis, dan interpretasi data naratif dan visual yang komprehensif (nonnumerik) untuk mendapatkan wawasan tentang fenomena menarik tertentu (Gay et al. 2012).

Dalam pengumpulan data penelitian kualitatif, yang diutamakan adalah kualitas dari temuan objek data yang ditafsirkan dan kemudian dianalisis (Ratna 2004). Data yang dikumpulkan berupa teks dari novel Kim Ji-yeong, Lahir Tahun 1982 baik berupa kata, frasa, klausa dan kalimat, baik langsung maupun tidak langsung yang diujarkan oleh seluruh tokoh perempuan yang terdampak tindakan misoginisme yang terdapat di dalam novel tersebut. Proses analisis data meliputi pengurutan data, penyusunan ke dalam pola kategori dan satuan deskripsi dasar (Emzir, 2019). Data yang dikumpulkan terdiri dari nomor, bukti pernyataan di dalam novel, halaman, dan kategori yang mengacu pada aspek penelitian yang disatukan dalam tabel.

Berikutnya data dikumpulkan dan dikelompokkan berdasarkan kategori temuan yang merujuk pada aspek misoginisme. Selanjutnya kategori yang sudah dipilah dan direduksi kemudian dianalis dan dikaji sesuai aspek misoginisme dengan menggunakan pendekatan feminisme sebagaimana misoginisme merupakan bagian yang ada di dalamnya. Analisis data yang dilakukan mengacu pada model Bogdan \& Biklen (2007) di mana analisis data diperoleh dari data yang dikategorikan atau dikodekan sesuai dengan topik yang dianalisis; dengan tahapan sebagai berikut: (1) kodifikasi atau kategorisasi seperti konteks, setting, atau topik; (2) kodifikasi atau kategorisasi subjek atau objek yang berkaitan dengan topik yang dikaji (misalnya definitif, perspektif, atau cara berpikir); (3) proses kodifikasi atau kategorisasi berupa temuan yang telah diklasifikasi sesuai dengan topik yang dikaji; dan (4) selanjutnya diinterpretasi dan dideskripsi. Keabsahan yang dilakukan menggunakan triangulasi yaitu proses penguatan bukti dengan berkonsultasi pada pakar yang sesuai dengan topik penelitian (Emzir 2018). Hasil dari analisis data kemudian diinterpretasi dan dideskripsikan yang dikaitkan dengan teori feminisme dan misoginisme serta penelitian yang relevan mengenai hal tersebut.

HASIL DAN Kategorisasi pembahasan fenomena misoginisme yang terdapat pada novel PEMBAHASAN Kim Ji-yeong, Lahir Tahun 1982 dibagi ke dalam tiga latar yaitu: dalam area domestik, di masyarakat, dan di dalam institusi. Hal ini sesuai dengan pendapat Bogdan \& Biklen (2007), yaitu data yang dianalisis dikelompokkan berdasarkan tempat, latar, situasi, peristiwa, atau topik yang dikaji. 
Misoginisme Misoginisme dalam area domestik merupakan tindakan-tindakan misoginis dalam Area yang terjadi di dalam atau sekitar urusan yang terkait dengan keluarga Domestik sebagaimana berikut.

Ketidaksetaraan Ungkapan yang menyatakan mengenai ketidaksetaraan perlakuan dalam perlakuan keluarga ini mengacu pada ketidaksetaraan perlakuan anak laki-laki dan anak dalam keluarga perempuan.

(1) Kenangan masa kecil yang masih diingat Kim Ji-yeong adalah ketika ia mencicipi susu bubuk adiknya... Jadi, ketika ibunya menyiapkan susu untuk adiknya, Kim Ji-yeong mencolek susu bubuk yang jatuh ke lantai dan mencicipinya... Nenek yang tinggal serumah dengan mereka tidak suka jika Kim Ji-yeong makan susu bubuk adiknya. Jika ketahuan makan susu bubuk, ia akan dipukul. (Cho 2020, 22).

Kutipan di atas menunjukkan adanya tindakan misoginis, yaitu ketidakadilan perlakuan dalam keluarga yang tidak seimbang antara anak laki-laki dan perempuan. Eksklusivitas perlakuan yang didapatkan anak laki-laki dalam keluarga merupakan cerminan misoginisme dalam bentuk ketidaksetaraan seperti yang disampaikan oleh Anderson (2015).

Tekanan harus Berikut ujaran yang terdapat di dalam novel yang di utarakan oleh Oh Minmelahirkan anak laki-laki sook, yaitu ibu dari Kim Ji-yeong, yang secara implisit menginginkan untuk melahirkan anak laki-laki setelah anak pertama Kim Eun-yeong dan anak kedua Kim Ji-yeong adalah perempuan.

(2) Nenek sungguh menyayangi menantunya dan selalu dengan tulus berkata bahwa menantunya harus melahirkan anak laki-laki, harus memiliki anak laki-laki, sekurang-kurangnya dua. Ketika Kim Eun-yeong lahir, Ibu memeluk bayi yang baru lahir itu sambil menangis dan meminta maaf kepada mertuanya. "Tidak apa-apa. Anak kedua nanti mungkin saja laki-laki," hibur Nenek. Ketika Kim Ji-yeong lahir, Ibu memeluknya sambil menangis dan meminta maaf kepada Nenek. Kali ini pun Nenek menenangkannya, "Tidak apa-apa. Anak ketiga mungkin laki-laki. (Cho 2020, 25)

Kebahagiaan memiliki anugerah seorang anak seharusnya menjadi hal yang menggembirakan bagi seorang lbu namun berbeda ketika terdapat tekanan yang harus dilahirkan adalah anak laki-laki. Sebagaimana digambarkan dalam temuan ketika Oh Min-sook melahirkan anak perempuan dan disalahkan. Seperti dikatakan oleh Manne (2018) tindakan seperti yang menekan dan menyalahkan secara psikis tergolong dalam tindakan misoginis.

Tidakada Dalam sebuah keluarga yang terdiri dari suami, mertua,dan anak, dorongan dukungandari dan dukungan untuk tetap menjaga keharmonisan sangatlah diperlukan. keluarga Terlebih lagi bagi seorang istri atau seorang ibu yang sedang dalam kondisi mengandung. Jika hal tersebut tidak didapatkan kemungkinan akan berakibat buruk seperti halnya yang dialami oleh Oh Min-sook berikut ini.

(3) Ibu pergi ke rumah sakit sendirian dan 'menghapus' adik perempuan Kim Ji-yeong. Semua itu bukan pilihan Ibu, tetapi entah bagaimana semua itu menjadi tanggung jawabnya. Tidak ada anggota keluarga yang menghiburnya sementara jiwa dan raganya tersiksa. Dokter menggenggam tangan lbu dan meminta maaf, sementara Ibu menangis meraung-raung seperti hewan yang kehilangan anaknya. Kata-kata 
hiburan dari dokter tua itulah yang membuat lbu tetap mempertahankan kewarasannya. (Cho 2020, 27)

Kutipan di atas menggambarkan kondisi fisik yang sangat menyakitkan. Namun, lebih menyakitkan kondisi psikis dan mental karena keharusan untuk menggugurkan bayi demi menjaga stabilitas ekonomi keluarga dan tuntutan untuk melahirkan anak laki-laki. Ditambah lagi tidak ada seorang pun yang mendampingi Oh Min-sook ketika dilakukan pengguguran janin dan sesudahnya. Oh Min-sook melakukan hal tersebut disebabkan karena suami tidak mendukungnya ketika ia akan melahirkan anak perempuan sehingga dengan terpaksa ia melakukan semuanya sendiri. Sementara dari anggota keluarganya, baik dari pihak suami maupun mertua, tindakan misoginis yang diluapkan secara implisit merasuk dan terngiang di dalam pikiran Oh Minsook. Hal ini sejalan dengan pemikiran Manne (2018) yang menyatakan bahwa tidak memberadakan perempuan juga termasuk dalam tindakan misoginis.

Pengorbanan perempuan bagi saudara laki-laki

Hal yang terkait dengan pengorbanan ini dimaksudkan mengesampingkan keinginan pribadi demi kepentingan saudara laki-laki yang masih satu keluarga, pernyataan tersebut adalah sebagai berikut.

(4) Karena kakak perempuannya yang berusia dua tahun lebih tua bekerja di pabrik tekstil di Cheonggyecheon di Seoul, ibu Kim Ji-yeong pun bekerja di pabrik yang sama dan tinggal bersama kakaknya di satu kamar sempit. Sebagian besar pegawai pabrik adalah gadis-gadis sebaya mereka... Selain usia yang sebaya, tingkat pendidikan dan latar belakang keluarga mereka juga serupa... Sebagian besar dari sedikit uang yang dihasilkan setelah bekerja sepanjang siang dan malam sampai wajah mereka cekung akan digunakan untuk biaya pendidikan saudara laki-laki mereka. Masa itu adalah masa ketika anak laki-laki dianggap sebagai seseorang yang harus menjadi tulang punggung keluarga, dan anak laki-laki adalah inti dari kesuksesan dan kebahagiaan keluarga. Anak-anak perempuan pun dengan senang hati mendukung saudara laki-laki mereka. (Cho 2020, 32)

Kutipan di atas memperlihatkan adanya pengorbanan dari seorang kakak perempuan demi adik laki-lakinya untuk melanjutkan studi karena di dalam keluarganya ditanamkan kepada anak-anak perempuan bahwa anak lakiakan memberikan kesuksesan kepada keluarganya. Oleh karena itu, anak perempuan tidak memprioritaskan pendidikan tetapi lebih memilih bekerja keras agar dapat mendukung kesuksesan saudara laki-laki mereka. Penanaman konsep bahwa anak perempuan harus berkorban demi anak lakilaki merupakan tindakan yang termasuk ke dalam misoginisme sesuai dengan pendapat Anderson (2015).

Ketidaksetaraan Setiap manusia berhak untuk mewujudkan sebuah impian. Tidak terkecuali dalam seorang anak perempuan. Akan tetapi, ini tidak terjadi pada Ibu Kim Ji-yeong, mewujudkan yakni Oh Min-sook yang tidak memiliki kesempatan untuk meraih mimpi impian karena harus memenuhi kebutuhan pendidikan adik-adiknya dan kemudian menjadi seorang ibu sebagaimana dapat dibaca pada kutipan di bawah ini.

(5) "Mama juga tadinya ingin menjadi guru." Kim Ji-yeong tertawa, karena baginya ibunya hanyalah seorang ibu. "Sungguh. Ketika lbu masih duduk di bangku SD, di antara kami lima bersaudara, Ibu yang paling pintar. "'Kalau begitu, kenapa Ibu tidak menjadi guru?" "Karena Ibu harus bekerja untuk menyekolahkan paman-pamanmu. Itulah yang dilakukan semua orang,. Pada masa itu, para wanita hidup sepertí itu." "Kalau 
begitu, Ibu bisa menjadi guru sekarang. "Sekarang Ibu harus mencari uang untuk menyekolahkan kalian. Itulah yang dilakukan semua orang, Pada masa sekarang itulah yang dilakukan para ibu." Ibu menyesali hidupnya sekarang. Hidupnya setelah menjadi seorang ibu. Seolah-olah hidupnya tertahan sebongkah batu berat. Kim Ji-yeong sedih berpikir dirinya adalah batu itu. Seolah-olah menyadari perasaan putrinya, Ibu pun mengusap-usap rambut putrinya yang acak-acakan dengan penuh kasih sayang. (Cho 2020, 34)

Pernyataan Oh Min-sook mensiratkan penyesalan di mana ia tidak memiliki kesempatan untuk mewujudkan impiannya yang disebabkan tanggung jawab demi tanggung jawab yang dia pikul ataupun terpaksa ia pikul di masa ia masih remaja. Perlakuan yang diterima oleh Oh Min-sook juga termasuk dalam misoginisme di mana ia tidak memiliki hak dalam menggapai apa yang diimpikannya. Hal ini sejalan dengan aspek misoginisme yang dikemukakan oleh Anderson (2015).

Ketidaksetaraan Hak di dalam keluarga semestinya diberikan secara adil dan merata. Namun, hak dalam tidak demikian halnya di dalam pola pemikiran keluarga Kim Ji-yeong yang keluarga beranggapan bahwa hak yang didapatkan anak laki-laki haruslah di nomorsatukan seperti terliat pada pernyataan berikut.

(6) Ayah dan Nenek pernah berkata bahwa anak- anak perempuan seharusnya sekamar dengan Nenek dan anak laki-laki seharusnya memiliki kamar sendiri. Namun, keputusan Ibu tak tergoyahkan. (Cho 2020, 46)

Dalam pernyataan di atas tergambar bahwa aturan dalam keluarga selalu mendahulukan hak laki-laki atau bahkan memberikan hak yang istimewa untuk anak laki-laki dibanding anak perempuan dan hal ini juga tergolong dalam perlakuan misoginis seperti yang disampaikan oleh Anderson (2015).

Misoginisme di Kekerasan secara fisik tidak hanya dilakukan oleh pria tetapi bisa juga oleh Masyarakat wanita. Tindakan semacam ini bisa dipicu oleh beberapa faktor, misalnya Kekerasan fisik kebencian, kecemburuan, kesenjangan, dan sebagainya seperti dapat dilihat pada kutipan di bawah ini.

(7) Ibu menerima bayaran dengan uang tunai dan tidak membayar pajak. Walaupun rambutnya pernah dijambak oleh pemilik salon lain karena Ibu dituduh merampas pelanggan- pelanggan, Ibu sudah lama tinggal di daerah itu, sehingga semua orang memihaknya. (Cho 2020, 31)

Bentuk kekerasan fisik yang dialami Oh Min-sook merupakan tindakan yang dilakukan oleh sesama perempuan yang didasari atas kecemburuan mengenai permasalahan kesenjangan ekonomi akibat yang bersangkutan tidak bisa menerima persaingan bisnis dalam skala mikro. Hal demikian ini termasuk dalam perilaku misoginis karena adanya tuduhan yang tidak berdasar dan disertai dengan kekerasan yang dilakukan di depan publik, sebagaimana dikemukakan oleh Wachtell \& Wolf (2017).

Hinaan secara Kata-kata yang dilontarkan secara tidak baik dan merendahkan dengan verbal bahasa yang kasar seperti hinaan terlebih lagi dilakukan di ruang publik merupakan tindakan misoginis seperti yang terdapat pada kutipan di bawah ini.

(8) Si anak laki-laki menyumpah, "Dasar Jalang." Lalu berderap pergi. (Cho 2020, 65) 
Pernyataan diatas dilontarkan oleh teman laki-laki kursus Kim Ji-yeong. Kim Ji-yeong tidak begitu mengenalnya dan menolak untuk berteman dengan laki-laki tersebut sehingga menyebabkan laki-laki tersebut menjadi gusar dengan mengucapkan kata-kata yang menghina. Sebagaimana dikemukakan oleh Manne (2018), hinaan secara verbal termasuk dalam kategori misoginisme.

Ketidaksetaraan terhadap penyebab pelecehan marga anak mengikuti marga ayah

Tekanan untuk melahirkan anak setelah menikah
Pemikiran yang cenderung menyalahkan perempuan ketika terjadi pelecehan dianggap wajar tanpa melihat runut permasalahannya terlebih dahulu juga merupakan tindakan misoginis seperti dalam perkataan ayah Kim Ji-yeong dibawah ini.

(9) Namun, hari itu Kim Ji-yeong dimarahi ayahnya. Kenapa ia harus kursus di tempat sejauh itu? Kenapa ia berbicara kepada sembarang orang? Kenapa ia memakai rok sependek itu? la harus banyak belajar. la harus berhati-hati, harus berpakaian pantas, harus bersikap pantas. la harus menghindari jalan yang berbahaya, waktu yang berbahaya, dan orang yang berbahaya. Kalau ia sampai tidak sadar dan tidak menghindar, maka ia sendiri yang salah. (Cho 2020, 65-66)

Pada kutipan di atas, ayah Kim Ji-yeong cenderung menyalahkan Kim Jiyeong tanpa menyelidiki atau bertanya penyebab terjadinya pelecehan verbal dengan memberikan nasihat yang bersifat implisit seperti menyudutkan dengan menyatakan apa yang terjadi merupakan kesalahannya sendiri dan bukan berasal dari pihak laki-laki yang melakukan pelecehan verbal. Hal tersebut termasuk ke dalam kategori misoginisme yang dikemukakan oleh Anderson (2015), Manne (2018), dan Ukockis (2019).

Penggunaan nama marga di Korea mengikuti marga Ayah. Nama anak akan dianggap aneh dan tidak lazim jika mengikuti marga Ibu. Hal ini akan terjadi jika Kim Ji-yeong memiliki anak. Masalah patriarki semacam ini juga tergolong dalam misoginisme sebagaimana terdapat pada kutipan berikut ini.

(10) "Sebagian besar orang masih mengikuti marga ayah. Orang-orang pasti berpikir ada yang aneh jika seorang anak mengikuti marga ibu. Dan kita terpaksa berulang kali memberikan penjelasan, koreksi, dan penegasan," kata Jeong-Dae hyeon. (Cho 2020, 132)

Dalam kutipan di atas ditunjukkan bahwa bagi seorang perempuan tidak lazim apabila anaknya mengikuti marganya. Ini menunjukkan bahwa kedudukan atau eksistensi perempuan berada di bawah posisi laki-laki sehingga perempuan tidak memiliki ruang untuk memberikan nama marga kepada keturunannya. Dengan kata lain, disiratkan bahwa garis keturunan laki-laki dianggap lebih menonjol dibanding garis keturunan perempuan. Patriarki semacam ini termasuk dalam kategori misoginisme seperti yang dikemukakan oleh Sharawi (2017).

Ketika perempuan sudah menikah, maka ia akan dituntut secara implisit untuk segera memiliki keturunan. Hal ini menjadi permasalahan besar terlebih lagi apabila pihak perempuan yang dipersalahkan. Perlakuan menekan seperti ini juga termasuk dalam misoginisme seperti ditunjukkan pada kutipan berikut.

(11) Kim Ji-yeong tidak muda lagi, tubuhnya terlalu kurus, tangannya dingin dan peredaran darahnya tidak lancar, dagunya yang berjerawat 
menandakan rahimnya tidak bagus... Pokoknya, seakan-akan masalahnya ada pada diri Kim Ji-yeong. (Cho 2020, 133)

Pada kutipan di atas dijelaskan bahwa, setelah menikah, perempuan harus dapat memberikan keturunan pada suami. Jika tidak terlaksana, maka pihak perempuan yang akan dipersalahkan sebagai faktor penyebab belum diberikannya keturunan. Hal demikian ini merupakan tindakan yang tidak setara karena hanya pihak perempuan yang dijadikan sebagai kambing hitam, sedangkan pihak laki-laki tidak dipersalahkan sama sekali. Dengan kata lain, ini merupakan perlakuan yang tidak setara karena keturunan merupakan permasalahan pasangan, baik dari pihak laki-laki maupaun pihak perempuan seperti yang dikemukakan oleh Anderson (2015), Manne (2018), dan Sharawi (2017).

Misigonisme Tindakan misoginisme dalam institusi dalam bentuk tidak adanya dukungan dalam institusi dari guru terkait dengan permasalahan antara siswa laki-laki dan perempuan Tidak ada dapat dilihat pada kutipan berikut.

dukungan dari guru $S D$

\section{Ketidaksetaraan perlakuan terhadap murid perempuan di $S D$}

(12) Ketika gurunya bertanya apakah ada yang ingin dikatakannya, Kim Jiyeong berkata sambil terisak, "Tolong pindahkan dia ke bangku lain. Saya tidak mau duduk sebangku lagi dengannya. Gurunya tersenyum. "Anak laki-laki biasanya sering mengganggu anak perempuan yang mereka sukai. Jadi sebaiknya kau tidak salah paham dan meminta teman sebangku yang baru. Kuharap kalian berdua bisa bergaul dengan lebih baik mulai sekarang." (Cho 2020, 38-39)

Kutipan di atas adalah gambaran bentuk luapan hati Kim Ji-yeong yang selalu dijahili oleh teman sebangkunya yang laki-laki. Namun, ketika ia menyampaikan keluhan kepada gurunya, ia tidak mendapat dukungan. Bahkan ia harus berupaya untuk bisa menerima kondisi yang ada meskipun itu membuatnya merasa tidak nyaman. Peristiwa ini merupakan salah satu tindakan misoginis, yaitu memaksa perempuan untuk menerima kondisi yang tidak nyaman dan menganggap suatu hal yang normal apbila diperlakukan secara tidak baik oleh laki-laki. Dengan kata lain, secara tidak langsung, ini seperti pembungkaman pendapat (Manne 2018).

Misoginisme di lingkungan institusi yang terkait dengan ketidaksetaraan perlakuan murid perempuan di sekolah dasar (SD) tampak pada kutipan berikut.

(13) Tetapi saat itu Kim Ji-yeong masih belum menyadarinya. Kenapa anak laki-laki mendapat nomor urut awal? Rasanya wajar apabila laki-laki mendapat nomor satu, apabila laki-laki yang mendapat nomor urut awal, dan apabila laki-laki selalu didahulukan. Anak laki-laki selalu menempati barisan depan, selalu bergerak lebih dulu, selalu dipanggil lebih dulu, dan PR mereka selalu diperiksa lebih dulu. Sementara itu para anak perempuan menunggu giliran tanpa suara, kadang-kadang merasa bosan, kadang-kadang merasa beruntung, dan sama sekali tidak merasa aneh. Seolah-olah nomor Jaminan Sosial untuk pria adalah 1 dan nomor untuk wanita adalah 2. (Cho 2020, 43-44)

Pernyataan diatas menunjukkan perlakuan istimewa terhadap murid laki-laki yang selalu didahulukan karena gender mereka dibandingkan murid perempuan. Tindakan demikian juga termasuk ke dalam misoginis, yakni perempuan disisihkan atau dinomorduakan setelah laki-laki (Anderson 2015). 
Ketidaksetaraan lainnya yang didapati Kim Ji-yeong adalah ketika ada kecenderungan bahwa yang dipilih menjadi ketua kelas adalah murid lakilaki, meskipun murid perempuan memiliki kompetensi yang sama atau bahkan lebih baik daripada murid laki-laki seperti dapat diamati pada kutipan berikut.

(14) Mereka sering berkata bahwa anak perempuan lebih pintar. juga merasa murid perempuan lebih tekun, tenang, dan teliti, tetapi ketika mereka memilih ketua kelas, mereka selalu memilih anak laki-laki. Ini bukan pengalaman Kim Ji-yeong sendiri. Pada masa itu, sebagian besar ketua kelas memang anak laki-laki. (Cho 2020, 44)

Dari kutipan diatas terlihat adanya ketidaksetaraan antara laki-laki dan perempuan. Bahkan di jenjang sekolah dasar, perempuan tidak memiliki kesempatan untuk mendapatkan posisi sebagai pemimpin, meskipun kompetensinya lebih baik. Ketidaksetaraan semacam ini juga tergolong dalam tindakan misoginis (Anderson 2015).

Ketidaksetaraan perlakuan

terhadap murid perempuan di SMP

Perlakuan yang tidak setara terhadap murid perempuan juga terjadi di jenjang SMP seperti kejadian yang terdapat dalam kutipan berikut ini.

(15) Dilarang mengenakan sepatu olahraga, hanya boleh mengenakan sepatu biasa. Berkeliaran di tengah musim dingin hanya dengan stoking dan sepatu biasa tanpa kaus kaki membuat anak-anak perempuan merasa begitu kedinginan sampai mereka ingin menangis. Untuk murid laki-laki, mereka tidak boleh sengaja membuat celana panjang mereka terlalu longgar atau terlalu sempit, tetapi para guru biasanya menutup sebelah mata menyangkut hal itu. Ada yang mengenakan singlet di balik kemeja, ada juga yang mengenakan kaus lengan pendek, dan bahkan kaus berwarna abu-abu atau hitam. Ketika cuaca sedang panas, mereka melepas beberapa kancing kemeja, atau mereka bahkan akan berkeliaran dengan kaus dalam mereka di saat makan siang atau di waktu istirahat. Mereka boleh mengenakan sepatu biasa, sepatu olahraga, sepatu sepak bola, dan bahkan sepatu lari. (Cho 2020, 52-53)

Tindakan misoginis pada kejadian di atas dapat dilihat dari perbedaan dalam memberikan kelonggaran terhadap aturan penggunaan pakaian sekolah. Siswa perempuan harus selalu menaati peraturan, sedangkan murid laki-laki cenderung diberikan kelonggaran untuk melanggar aturan. Hal demikian ini menunjukkan adanya perlakuan yang tidak setara terhadap laki-laki dan perempuan. (Anderson 2015)

Tindakan Tindakan yang tidak menghormati perempuan secara biologis, seperti pelecehan seksual pelecehan seksual, juga termasuk dalam perbuatan misoginis dan ini terjadi diSD juga di jenjang sekolah dasar seperti tercermin dalam kutipan di bawah ini.

(16) Ketika Kim Ji-yeong masih duduk di kelas 1 sekolah dasar, wali kelasnya adalah seorang pria berusia lima puluh tahun. la suka membawa alat penunjuk berbentuk jari telunjuk ke mana-mana. Lalu dengan alasan memeriksa label nama di seragam murid, ia akan menusuk-nusuk dada anak-anak perempuan dengan alat penunjuknya. Atau ia akan mengangkat rok mereka dengan alasan memeriksa seragam mereka. (Cho 2020, 61-62)

Pada kutipan di atas terlihat adanya tindakan pelecehan seksual yang dilakukan oleh seorang pendidik terhadap siswa perempuan. Seperti yang 
dikemukakan oleh Sharawi (2017), pelecehan seksual merupakan tindakan yang termasuk dalam tindakan misoginis.

Ketidaksetaraan Misoginisme dalam bentuk ketidaksetaraan posisi dalam organisasi di posisi organisasi perusahaan di sini berkaitan dengan jabatan, yaitu perempuan tidak memiliki di perusahaan hak yang sama dengan laki-laki dalam menduduki jabatan. Misalnya, tidak ada kesempatan bagi perempuan untuk menjadi ketua organisasi.

(17) Namun demikian, mereka berkata bahwa klub mereka sukses berkat para anggota pria yang santai, kuat, dan bisa bergaul dengan baik dengan sesama anggota. Posisi ketua, wakil ketua, dan manajer dijabat oleh pria. (Cho 2020, 89)

Posisi sebagai pemimpin organisasi di perusahaan didominasi oleh laki-laki, sementara perempuan tidak memiliki kesempatan untuk menduduki posisi tersebut. Stereotipe bahwa laki-laki harus menjadi pemimpin juga sudah menjadi hal yang biasa di perusahaan. Hal ini menunjukkan bahwa tindakan misoginis merupakan hal yang sudah dianggap lumrah. Konsep ini sejalan dengan pemikiran (Sharawi 2017).

Ketidaksetaraan Perekrutan karyawan yang tidak setara dalam memberikan peluang atau dalamperekrutan kesempatan karena perbedaan gender juga termasuk dalam tindakan karyawan misoginis seperti terdapat dalam kutipan berikut ini.

(18) Perusahaan akan merasa terbebani apabila seorang wanita terlalu pintar. Coba lihat sekarang, apakah kau tahu betapa mengintimidasinya dirimu? Lalu bagaimana? Pintar salah, bodoh salah, melakukan sesuatu setengah-setengah juga salah. Karena merasa perlawanannya tidak ada artinya, kakak senior perempuan itu pun berhenti memprotes. (Cho 2020, 95-96)

Pada kutipan di atas dapat dilihat bahwa ketimpangan peluang dalam perekrutan karyawan terjadi karena faktor gender di mana perempuan menjadi sosok yang serba salah. Terlalu pandai salah, setengah-setengah juga tidak benar. Apalagi jika kemampuannya kurang. Ketidaksetaraan seperti ini sejalan dengan pendapat Anderson (2015) sebagai salah satu bentuk misoginisme.

Ketidaksetaraan

Ketidaksetaraan jabatan di dunia kerja adalah tidak setaranya kesempatan jabatan di dunia untuk menduduki posisi yang lebih tinggi seperti kepala bagian, manajer, kerja atau direksi yang mengindikasikan adanya ideologi misoginisme seperti ditunjukkan oleh kutipan berikut.

(19) Pada akhir tahun, perusahaan itu membuka lowongan pekerjaan untuk umum dan si kakak senior berhasil diterima bekerja di sana. "Wah, hebat. Jadi sekarang dia bekerja di perusahaan itu?" "Tidak. Dia berhenti bekerja setelah enam bulan." Suatu hari kakak senior perempuan tersebut menyadari bahwa tidak ada seorang wanita pun yang menduduki jabatan kepala bagian.... Sang direktur tahu benar bahwa tuntutan pekerjaan akan membuat karyawan wanita sulit menyeimbangkan kewajiban profesional dan perkawinan mereka, terutama apabila mereka sudah memiliki anak. Karena itu sang direktur tidak menganggap karyawan wanita sebagai karyawan jangka panjang. (Cho 2020, 122)

Pada kutipan di atas terlihat perspektif dari seorang atasan terhadap bawahan, yaitu status sudah berkeluarga dan memiliki anak pada perempuan 
merupakan penghambat dalam dunia kerja sehingga perempuan tidak diberi peluang untuk mengembangkan kariernya. Pandangan ini didasari anggapan bahwa urusan domestik seperti mengurus rumah tangga dan anak merupakan tanggung jawab perempuan sehingga akan sulit bagi perempuan untuk menyeimbangkan antara keluarga dan karir. Perbuatan semacam ini termasuk ke dalam misoginisme dalam bentuk merendahkan dan meremehkan perempuan sebagaimana dinyatakanAnderson (2015), Manne (2018), dan Sharawi (2017).

Pertanyaan Dalam wawancara kerja, calon karyawan perempuan seolah-olah seputar pelecehan dalam wawancara kerja dipersepsikan akan berada pada situasi terdampak pelecehan. Perlakuan semacam ini tentu saja merupakan tindakan misoginis. Contoh kejadiannya dapat dilihat pada kutipan di bawah ini.

(20) Anggaplah kalian pergi menemui klien di luar kantor Tetapi si klien terus berusaha melakukan kontak fisik, Misalnya menyentuh bahu atau paha kalian. Kalian mengerti maksudku, bukan? Lalu apa yang akan kalian lakukan Silakan dijawab, mulai dari Kim Ji-yeong Kim Ji-yeong tahu ia tidak boleh terlihat bingung seperti orang bodoh, la juga berpikir sikap yang terlalu serius tidak akan membuatnya mendapat nilai baik, jadi ia pun menjawab, "Aku akan menghindar dengan alasan pergi ke kamar kecil atau pergi mengambil berkas-berkas lain." (Cho 2020, 100)

Pada kutipan di atas dapat dilihat bahwa pertanyaan yang diajukan terhadap pelamar kerja perempuan tidak objektif berdasarkan kemampuan profesional sesuai dengan pekerjaan yang akan diambil tetapi lebih mencerminkan adanya pelecehan terhadap perempuan dan hal ini tentu saja termasuk dalam tindakan misoginisme (Ukockis 2019).

Pelecehan secara verbal di lingkungan kerja

Ketidaksetaraan penghasilan di dunia kerja

Pelecehan verbal berupa penyampaian kata-kata yang tidak sopan atau tidak pantas yang ditujukan untuk merendahkan perempuan seperti terlihat pada kutipan berikut ini.

(21) la bahkan melontarkan lelucon-lelucon yang tidak senonoh dan tidak lucu seperti "Gol yang berhasil dicetak di gawang yang dijaga baru akan terasa memuaskan." Atau "Ada wanita yang belum pernah melakukannya, tetapi tidak ada wanita yang hanya melakukannya satu kali." (Cho 2020, 115)

Kutipan di atas berisi lelucon yang merendahkan perempuan dan dilontarkan di depan banyak orang di lingkungan kerja. Tindakan semacam ini termasuk dalam misoginisme (Ukockis 2019).

Ketidaksetaraan penghasilan di dunia kerja ini berupa perbedaan upah antara karyawan laki-laki dan perempuan. Karyawan laki-laki diberikan upah lebih tinggi daripada karyawan perempuan. Ketidaksetaraan semacam ini juga termasuk dalam misoginisme sebagaimana dicontohkan kutipan berikut.

(22) Kim Ji-yeong tahu sejak mereka bergabung dengan perusahaan, pendapatan tahunan para rekan kerja pria pasti lebih tinggi, tetapi ia tidak merasakan apa-apa lagi karena kekagetan dan kekecewaan yang dirasakannya hari itu sudah terlalu besar. (Cho 2020,123)

Temuan di atas menunjukkan adanya ketidakadilan dalam hal pendapatan, yaitu karyawan laki-laki dibayar lebih tinggi dibandingkan karyawan perempuan. Ini merupakan suatu bentuk perlakuan misoginis, yaitu penghasilan yang diberikan tidak secara objektif didasarkan pada 
kemampuan dan keterampilan karyawan tetapi justru dibedakan meurut jenis kelamin (Anderson 2015, Manne 2018).

Pelecehan Pelecehan merupakan tindakan yang merendakan menyakiti perempuan seksualdidunia secara fisik dan psikis terlebih lagi apabilaterjadi di lingkungan pekerjaan.

kerja Tindakan misoginis semacam ini dapat dilihat pada kutipan berikut.

(23) Ada kamera tersembunyi yang ditemukan di toilet wanita yang berada tepat di depan ruang kerja mereka. Pelakunya adalah salah seorang pria berusia 20-an yang bekerja sebagai petugas keamanan di gedung itu. Tahun lalu, perusahaan mereka menandatangani kontrak dengan perusahaan keamanan baru, dan mereka mengganti para petugas keamanan yang sudah tua dengan anak-anak muda. Sebagian orang berkata bahwa mereka merasa lebih tenang dengan adanya petugaspetugas keamanan yang masih muda, tetapi Sebagian lain berkata bahwa mereka justru merasa lebih takut orang pada petugas keamanan daripada pencuri. Kim Ji-yeong bertanya-tanya ke mana perginya para petugas keamanan yang dulu. Yang lebih menyedihkan adalah bagaimana keberadaan kamera tersembunyi itu akhirnya diketahui. Si petugas keamanan memasang serangkaian foto-foto yang diambilnya secara diam- diam di salah satu situs khusus dewasa, yang kemudian ditemukan oleh salah seorang manajer pria dari kantor mereka yang Juga adalah anggota situs itu. Dan menyebarkan foto-foto itu ke teman kerja pria lainnya. (Cho 2020, 153-154)

Kejadian di atas merupakan gambaran kemajuan teknologi yang dimanfaatkan sebagai alat untuk melakukan hal yang menjatuhkan martabat perempuan, tidak hanya secara individu tetapi juga secara kolektif. Peristiwa semacam ini dapat diklasifikasikan sebagai misoginisme yang terjadi di zaman modern sebagaimana pemikiran Anderson (2015), David (2016), Mantilla (2015), Tracy \& Everbach (2018), dan Zuckerberg (2018).

Ketidaksetaraan perlakuan di dunia kerja
Perlakukan yang berbeda antara karyawan laki-laki dan karyawan perempuan yang mencerminkan ketidaksetaraan di dunia kerja juga termasuk perlakuan misoginis seperti terdapat dalamkutipan berikut ini.

(24) la sudah menuntut pernyataan maaf, janji bahwa hal seperti ini tidak akan terjadi lagi, dan menuntut hukuman untuk orang-orang yang bertanggung jawab, tetapi direktur mereka justru mencoba menutupnutupi kasus ini. "Apa yang akan terjadi pada perusahaan ini kalau semua orang sampai tahu? Kita tidak mungkin merusak kehidupan mereka bukan? Semua karyawan pria memiliki keluarga dan wanita juga yang akan dirugikan apabila semua orang tahu foto-foto kalian tersebar luas". Sang direktur benar-benar memiliki pikiran yang jauh lebih sempit dibandingkan orang-orang sebaya dirinya. Mendengar pernyataan konyol, defensif, egois, dan penuh pembelaan diri yang meluncur dari mulut sang direktur, Kim Eun-sil tidak bisa menahan diri lagi dan berkata, "Punya istri dan orangtua bukan alasan untuk memaafkan perbuatan seperti itu. Justru sebaliknya. Sebaiknya Anda mengubah jalan pikiran Anda. Jika Anda terus hidup dengan pola pikir seperti itu, walaupun Anda beruntung bisa menghindari masalah kali ini, hal seperti ini akan terjadi lagi." (Cho 2020, 156)

Kutipan di atas menunjukkan adanya perlakuan yang istimewa pada seorang karyawan laki-laki yang telah membua kesalahan. Di sini terlihat adanya 
pandangan absurd bahwa jika keadilan ditegakkan maka akan berdampak tidak baik bagi korban. Seperti yang dikemukakan oleh Anderson (2015), ketidaksetaraan dan ketidakadilan terhadap perempuan merupakan tindakan misoginisme.

Ketidaksetaraan untuk mendapatkan pekerjaan setelah berkeluarga

Di dunia kerja, perempuan yang sudah berhenti bekerja karena menikah dan punya anak akan sulit mendapatkan kembali pekerjaan yang sama dengan sebelum ia berkeluarga. Kesulitan seperti ini merupakan akibat dari ketidaksetaraan perlakuan di duania kerja dan termasuk dalam tindakan misoginis. Contoh kejadiannya dapat dilihat pada kutipan di bawah ini.

(25) Ketika hendak melamar kerja kembali setelah menikah dan mengundurkan diri dari perusahaan sebelumnya, kemungkinan besar wanita hanya akan diterima di perusahaan- perusahaan kecil dengan jumlah karyawan kurang dari empat orang. Kesempatan mereka bekerja di bidang industri atau manajerial juga mengecil. Mereka akan lebih banyak mendapat pekerjaan yang berhubungan dengan penyewaan akomodasi, restoran, dan penjualan. Tentu saja, gaji yang didapat tidak terlalu bagus, seperti menjadi kasir, pelayan restoran, agen pemurni air, dan dengan kebijakan penitipan anak gratis, orang-orang berkata bahwa para ibu muda zaman sekarang menitipkan anak-anak mereka ke tempat penitipan supaya mereka sendiri bisa pergi minum kopi, melakukan perawatan kuku, dan berjalan-jalan di mal. Namun pada kenyataannya, hanya sebagian kecil orang berusia 30 -an yang memiliki kekuatan ekonomi sebesar itu di Korea Selatan. Justru lebih banyak ibu yang mendapat gaji minimum dengan menyajikan makanan di restoran dan kafe, merawat kuku orang lain, dan menjual barang-barang di supermarket. (Cho 2020, 159)

Kutipan di atas menunjukkan bahwa kesempatan untuk mendapatkan pekerjaan bagi perempuan yang sudah berkeluarga tidak sama dengan lakilaki yang bisa bekerja lagi kapan saja. Hal ini menunjukkan adanya ketidaksetaraan yang berakibat pada terbatasnya lapangan pekerjaan bagi perempuan yang sudah berkeluarga. Dalam hal ini, seharusnya yang dilihat adalah kemampuan kerja dan bukan semata-mata status perempuan sebagai seorang istri atau ibu. Menurut Anderson (2015), Manne (2018) Sharawi (2017), ketidaksetaraan gender semacam ini termasuk dalam tindakan misoginis.

Dari temuan di atas ketidaksetaraan yang diterima perempuan di dalam keluarga, masyarakat, dan institusi baik sebagai seorang anak, ibu, nenek, siswi sekolah, maupun karyawan di perusahaan, yang ditampilkan di dalam novel Kim Ji-Yeong, Lahir Tahun 1982 tidak sejalan dengan pemikiran feminisme yang disampaikan oleh Logan (2011) dan Mackay (2010), yaitu hak-hak perempuan dikesampingkan di atas kepentingan laki-laki yang seharusnya terdapat kesetaraan dan keseimbangan di antara keduanya. Dalam novel ini, banyak tokoh perempuan digambarkan hanya disibukkan dengan masalah domestik, seperti melahirkan, mengurus rumah tangga, menyiapkan keperluan keluarga dengan mengesampingkan keinginan sendiri untuk mewujudkan impian, mendapatkan pendidikan yang tinggi dan bahkan lebih banyak berkorban demi saudara, anak, dan keluarga. Hal-hal semacam ini menjadi aspek penting hadirnya feminisme seperti yang digagas oleh Cruz \& Languages (2012) dan Welch (2012).

Selain itu, dalam novel Kim Ji-Yeong, Lahir Tahun 1982, banyak tokoh perempuan yang dalam situasi sosial secara gender dilecehkan, 
dipersalahkan, direndahkan, dan tidak diberikan peluang atau kesempatan yang sama dengan yang dimiliki laki-laki. Hal ini bertentangan dengan ideologi feminisme yang memandang gender bukan merupakan penghalang untuk mencapai kesetaraan dan seharusnya laki-laki dan perempuan memiliki kedudukan yang sama dalam tataran sosial seperti yang diutarakan oleh Emzir \& Rohman, (2017) dan Suhariyadi (2014).

Tokoh perempuan dalam novel Kim Ji-Yeong, Lahir Tahun 1982, diceritakan sering sekali mendapatkan perlakuan misoginis baik dari piihak keluarga, masyarakat, institusi sekolah, dunia kerja, maupun organisasi. Tindakan misoginis di dalam keluarga diantaranya yaitu perlakuan yang berbeda antara anak laki-laki dan perempuan, tekanan harus melahirkan anak laki-laki, tidak mendapat dukungan dari keluarga ketika harus menggugurkan janin perempuan, berkorban untuk saudara laki-laki sehingga tidak bisa mengenyam pendidikan tinggi dan harus menjadi pekerja kasar atau serabutan, tidak mendapatkan kesempatan untuk menggapai mimpi, dan tidak memiliki hak yang sama dengan laki-laki di dalam keluarga. Hal-hal semacam ini sesuai dengan apa yang digambarkan oleh Sharawi (2017) dan Sunarto (2009) mengenai misoginisme.

Sementara itu, perlakuan misoginis di lingkungan masyarakat, pada novel Kim Ji-yeong, Lahir Tahun 1982, dicontohkan berupa kekerasan fisik terhadap Oh Min-sook yang rambutnya dijambak oleh pesaing bisnisnya, hinaan secara verbal kepad Kim Ji-yeong yang mengabaikan pria yang menyukainya, anggapan perempuan sebagai penyebab terjadinya pelecehan, budaya patriarki yang mengharuskan marga anak mengikuti marga ayahnya, dan tekanan terhadap perempuan menikah untuk segera melahirkan keturunan. Tindakan-tindakan seperti ini merupakan representasi dari misoginisme sebagaimana dijelaskan oleh Anderson (2015), Ukockis (2019), dan Wachtell \& Wolf (2017).

Sementara misoginisme dalam ruang institusi dalam novel Kim Ji-Yeong, Lahir Tahun 1982 dimunculkan dalam banyak hal, diantaranya tidak adanya dukungan dan kesetaraan bagi pembelajar perempuan atas ketimpangan yang dilakukan oleh pengajar dari jenjang sekolah dasar hingga perguruan tinggi; tidak diberikannya kesempatan untuk mendapatkan posisi atau jabatan, baik di ruang edukasi ataupun ruang kerja; pelecehan seksual baik secara verbal ataupun nonverbal di lingkungan pendidika maupun di lingkungan kerja, ketidakadilan dalam perekrutan karyawan; ketidaksetaraan penghasilan dengan jumlah jam kerja yang sama; dan ketidaksetaraan untuk bekerja kembali setelah menikah. Temuan di atas sesuai dengan konsep misoginis yang ditentang dalam faham feminis seperti yyang dituliskan oleh David (2016) Manne (2018) Mantilla (2015) Tracy \& Everbach (2018), dan Zuckerberg (2018).

Temuan yang didapatkan dalam novel Kim Ji-Yeong, Lahir Tahun 1982 ini tidak seekstrem dengan apa yang ditemukan oleh Fischer (2016); Magennis (2016) yang menyoroti tindakan misoginis dalam bentuk kekerasan seksual dan pembunuhan. Meskipun demikian, terdapat benang merah antara misoginisme di dalam novel tersebut dengan temuan Bala \& Blessy (2020) dan Nguyen et al. (2018) mengenai tindakan misoginis yang dihadapi oleh perempuan yang cenderung pada ketidaksetaraan terhadap perempuan dalam kaitannya dengan konteks kultural yang telah dipercaya secara turun termurun meskipun zaman atau generasi sudah berubah atau berbeda. 
Penggambaran yang dituliskan oleh Cha Nam-joo dalam novelnya adalah salinan atau potret kehidupan sebagian kecil perempuan yang hidup di dalam budaya Korea Selatan meskipun bingkai tersebut hanyalah fiksi, ia juga menuliskan:

(26) Kadang-kadang aku berpikir bahwa Kim Ji-yeong adalah tokoh nyata, karena ia sangat mirip dengan para teman wanitaku, rekan senior dan juniorku, bahkan diriku sendiri. Sebenarnya Kim Ji-yeong dalam buku ini terkesan sangat tertekan dan menyedihkan. Tetapi aku tahu bahwa ia tumbuh besar seperti itu, hidup seperti itu, dan tahu bahwa tidak ada jalan lain. Karena aku juga mengalaminya sendiri. (Cho 2020, 177)

Ini artinya, misoginisme yang dinarasikan di dalam novel Cha Nam-joo melalui tokoh-tokoh perempuan terinspirasi dari kehidupan nyata yang dialaminya. Sebagaimana dinyatakan oleh Croally \& Hyde (2011) bahwa karya sastra yang dihasilkan oleh penulis dapat terinspirasi dari budaya atau tradisi di lingkungan masyarakat penulis. Tokoh Kim Ji-yeong sendiri di akhir cerita dikisahkan mengalami depresi akibat lingkaran misoginisme yang ada di sekitarnya karena ia tidak dapat meluapkan, melawan, atau bahkan bertarung tetapi hanya bisa diam dan berkata dalam hati karena ia menyadari jika ia tidak memiliki kekuatan untuk itu (Cho 2020).

KESIMPULAN Keberadaan peristiwa-peristiwa misoginis yang disajikan dalam novel Kim Jiyeong, Lahir Tahun 1982 mungkin terjadi di dalam realita kehidupan dunia nyata baik di kota regional ataupun metropolitan dan baik di negara maju ataupun negara berkembang yang mana dampaknya merugikan bagi kaum perempuan baik secara mental, fisik, dan juga psikis. Meskipun diciptakan dari tulang rusuk Adam, tidak sepantasnya Hawa diperlakukan secara misoginis. Sebaliknya, sangat penting untuk menghormati dan menghargai kaum perempuan karena kaum laki-laki juga terlahir melalui rahim perempuan. Harus ada perlakuan setara dan seimbang antara laki-laki dan perempuan sebagaimana pandangan feminisme. Implikasi dari kajian ini adalah upaya untuk menghindarkan atau menjauhkan tindakan misoginis, khususnya bagi yang terdampak, yakni kaum perempuan.

DAFTAR PUSTAKA Abrams, MH. 1999. A Glossary of Literary Terms. Boston: Earl McPeek

Anderson, Kristin J. 2015. Modern Misogyny. New York: Oxford University Press

Arata, Stephen, Madigan Haley, J. Paul Hunter \& Jennifer Wicke. 2015. A Companion To The English Novel. West Sussex: John Wiley \& Sons, Ltd.

Bala, D, J Selva \& SJ Blessy. 2020. "Ignominy and Misogyny in Kiran Desai's The Inherintence of Loss." UGC Care Journal Studies in Indian Place Names 40 (41): 9094

Baldick, Chris. 2001. The Concise Oxford Dictionary of Literary Terms. Oxford: Oxford University Press

Benedetti, Lavinia. 2016. "The Political Aspect of Misogynies in Late Qing Dynasty Crime Fiction." Journal of Literature and Art Studies 6 (4): 340-355

Bogdan, Robert C \& Sari Knopp Biklen. 2007. Qualitative Research for Education An Introduction to Theory and Methods Fifth Edition. Boston: Pearson Education, Inc.

Brantly, Susan C. 2017. The Historical Novel, Transnationalism, and the Postmodern Era: Presenting the Past. Oxon: Routledge

Cho Nam-joo. 2020. Kim Ji-Yeong, Lahir Tahun 1982. Jakarta: PT Gramedia

Creswell, John W. 2012. Educational Research: Planning, Conducting, and Evaluating Quantitative and Qualitative Research. 4th ed. by PA Smith (ed). Boston: Pearson Education, Inc.

Croally, Neil, \& Roy Hyde. 2011. Classical Literature: An Introduction. New Jersey: Routledge 
Cuddon, JA. 1999. The Penguin Dictionary of Literature Terms and Literary Theory. New York: Penguin Books

Culler, Jonathan. 2000. Literary Theory: A Very Short Introduction. New York: Oxford University Press

David, Miriam E. 2016. Reclaiming Feminism Challenging Everyday Misogyny. Chicago: The University of Chicago Press

Drabble, Margaret. 2000. The Oxford Companion to English Literature. Oxford: Oxford University Press

Eagleton, Terry. 2005. Literary Theory An Introduction Second Edition. Victoria: Blackwell Publishing

Emzir. 2018. Metodologi Penelitian Kualitatif Analisis Data. Depok: PT RajaGrafindo Persada

Emzir \& Saifur Rohman. 2017. Teori dan Pengajaran Sastra. Depok: PT Rajagrafindo Persada

Fischer, Carlie. 2016. "Mermaids, Multiculturalism, and Misogyny in Vladimir Nabokov's." Verso: An Undergraduate Journal of Literary Criticism: 82-93.

Fowler, Peter \& Childs Roger. 2006. The Routledge Dictionary of Literary Terms. New York: Routledge

Holland, Rachel. 2019. Contemporary Fiction and Science from Amis to McEwan The Third Culture Novel. Cham: Springer Nature Switzerland AG

Kusch, Celena. 2016. Literary Analysis the Basics. New York: Routledge.

LR Gay, Geoffrey E Mills \& Peter Airasian. 2012. Educational Research : Competencies for Analysis and Applications. 10th Ed. Boston: Pearson Education, Inc.

Lamas, Marta. 2012. Feminism: Transmissions and Retransmissions. New York: Palgrave Macmillan

Logan, Peter Melville. 2011. The Encyclopedia of the Novel. Oxford: Blackwell Publishing.

Mackay, Marina. 2010. The Cambridge Introduction to the Novel. New York: Cambridge University Press.

Magennis, Caroline. 2016. "That's Not so Comfortable for You, Is It: The Spectre of Mysogyny in The Fall": 216-34 in The Body in Pain in Irish Literature and Culture. Cham: Springer International Publishing AG Switzerland

Manne, Kate. 2018. Down Girl The Logic of Misogyny. New York: Oxford University Press.

Mantilla, Karla. 2015. Gendertrolling How Misogyny Went Viral. California: ABC-CLIO, LLC.

Morris, Pam. 1993. Literature and Feminism. Oxford: Blackwell Publisher

Nguyen, Tiffany \& Willis Salomon. 2018. "What's Done Is Donne: Analyzing John Donne's Misogyny in Elegy 19." In Proceedings of The National Cenference of Undergraduate Research, 2018: 48-53 Oklahoma

Parker, Kate, \& Courtney Weiss Smith. 2014. Eighteenth-Century Poetry and the Rise of the Novel Reconsidered. Maryland: Bucknell University Press

Ratna, Nyoman Kutha. 2004. Teori, Metode, dan Teknik Penelitian Sastra. Yogyakarta: Pustaka Pelajar

Sharawi, Huda. 2017. Women between Submission and Freedom An Interpretation of Social and Political Misogyny. Rotterdam: Sense Publishers

Suhariyadi. 2014. Pengantar IImu Sastra: Orientasi Penelitian Sastra. Lamongan: Pustaka llalang

Sunarto. 2009. Televisi, Kekerasan, dan Perempuan. Jakarta: PT. Kompas Media Nusantara

Tracy, Jacqueline, Ryan Vickery \& Tracy Everbach. 2018. Mediating Misogyny Gender, Technology, \& Harassment. Denton: Springer International Publishing

Ukockis, Gail. 2019. Misogyny The New Activism. Oxford: Oxford University Press

Wachtell, Diane \& Naomi Wolf. 2017. Wolf Whistle Politics The New Misogyny in America Today. New York: The New Press

Welch, Shay. 2012. A Theory of Freedom Feminism and The Social Contract. New York: Palgrave Macmillan

Williams, James Reay. 2019. Multilingualism and the Twentieth- Century Novel. Cham: Springer Nature Switzerland AG

Zuckerberg, Donna. 2018. Not All Dead White Men Classics and Misogyny in the Digital Age. London: Harvard University Press

\section{Copyright @ 2020 Leksema: Jurnal Bahasa dan Sastra}

